In 1975 Matas and co-workers were the first in the world literature to show an increased risk of malignant tumor occurrence in the group of hemodialyzed patients and kidney transplant recipients. The report is an analysis of world literature from the last 35 years in reference to epidemiology as well as the profile of screening tests and diagnostic methods related to malignant tumors in the population with end stage renal disease, especially hemodialyzed patients.

Key words: neoplastic disease, end stage renal disease, hemodialysis, peritoneal dialysis.

\section{Malignant tumors in patients with end stage renal failure undergoing renal replacement therapy}

\author{
Grzegorz Kade ${ }^{1}$, Arkadiusz Lubas ${ }^{1}$, Lubomir Bodnar², Cezary Szczylik², \\ Zofia Wańkowicz ${ }^{1}$
}

1Department of Internal Disease, Nephrology and Dialysis Therapy, Central Clinical Hospital, Ministry of the Interior and Administration, Military Institute of Medicine, Warsaw, Poland

2Oncology Department, Central Clinical Hospital, Ministry of the Interior and Administration, Military Institute of Medicine, Warsaw, Poland

\title{
Introduction
}

An increase in incidence and morbidity of chronic kidney disease has been observed in Poland within the last ten years [1]. This results in an increasing number of patients who both suffer from end stage renal disease (ESRD) and require renal replacement therapy. Chronic kidney disease in both prehemodialysis patients and renal replacement therapy patients is connected with an increased risk of death, mainly due to cardiovascular diseases (56\%), infections (11.2\%) and neoplastic diseases (8\%) [1].

The current study is an analysis of world literature from the last 35 years with reference to epidemiology as well as the profile of screening tests and diagnostic methods related to malignant tumors in the population with ESRD, especially hemodialyzed individuals.

\section{Epidemiology of neoplastic diseases in patients with irreversible renal failure: has anything changed within the last 35 years? If yes - what?}

In 1975 Matas et al. were the first in the world literature to publish data on increased risk of malignant tumor occurrence in the group of patients on a hemodialysis program as well as renal transplant recipients. The study included a group of 646 patients. The risk of developing a malignant tumor in dialyzed individuals was estimated as seven-fold higher than in comparable age groups without renal failure [2]. According to the reports from the 1970s, the vast majority of authors confirmed these observations. In 1979 Kjellstrand et al. analyzed studies published in the 1970s on carcinogenesis in the dialyzed population. Most of the studies indicated a cause and effect relation between hemodialysis therapy and frequent occurrence of malignant tumor compared to the general population. The analysis considered the more frequent occurrence of urinary tract cancer and kidney cancer, especially in the course of polycystic kidney disease and analgesic nephropathy [3]. Kinlen et al. published in 1980 outcomes of a 10-year observation of 1651 patients from Great Britain on hemodialysis, peritoneal dialysis or who received kidney transplant. A greater frequency of non-Hodgkin lymphoma was observed compared to the general population [4]. Slifkin et al. did not confirm these observations in material which included 712 hemodialyzed patients observed for 10 years [5]. The greatest multicenter study in the 1980s was conducted by Jacobs et al. and involved 39386 hemodialyzed patients and renal transplant recipients. According to the study, malignant tumors were present in $1.3 \%$ of these patients. Among them, the most frequent was lung cancer, observed in $10 \%$ of this population [6]. 
According to the study of Lindner et al., which included 148 dialyzed patients, malignant tumor occurred in $9.5 \%$ of the individuals. Similarly to the study of Jacobs et al., the most frequently diagnosed neoplasm was lung cancer, which amounted to $50 \%$ of all the diagnosed tumors [7].

However, in the study of Bush et al. published in 1984 on 834 ESRD patients the percentage of diagnosed malignant tumors was as low as $0.6 \%$ of the examined population and was lower than the expected statistical significance level $p<0.05$ [8].

In the study conducted in 1989 on 4161 dialyzed patients, Port et al. attempted to evaluate the risk of developing malignant tumor considering race, gender and age of the patients. Malignant tumors occurred considerably more frequently in dialyzed patients compared to the general population and all tumors in situ as well as kidney, endometrial, cervical and prostatic cancers [9].

One of the carcinogenesis risk factors is chronic immunosuppressive therapy. In the study of Pecqueux et al. from 1990 the authors compared a group of 709 kidney transplant recipients with a group of 317 dialyzed patients. Malignant tumor developed in 3\% of transplant recipients and in 10\% of dialyzed individuals [10].

In the 1990 s a few large epidemiologic studies were reported. In the study on 23209 patients dialyzed in 589 centers in Japan, Inamoto et al. observed an increased risk of developing malignant tumor and mortality compared to the general population. The most frequently diagnosed disease was cancer of digestive and urinary tracts. Also, malignant tumors occurred in men much more frequently than in women. In this study, diagnosis of malignant tumor was most often made within the first 6 months of hemodialysis therapy [11]. Similarly, according to the study conducted in Serbia by Čučković et al. on 923 hemodialyzed patients between 1983 and 1993, 40\% of malignant tumors were diagnosed within the first year of hemodialysis therapy. Mean age of the patients was approximately 59 years [12].

The largest study on malignant tumor occurrence in hemodialyzed patients was a multicenter study in 1999 conducted by Maisonneuve et al. on 831804 patients from North America, Europe, Australia and New Zeeland (the study was based on USRDS, EDTA and ANZDTR data). In the course of a 30-month observation, malignant tumors were diagnosed in 25044 patients, which amounted to 3\% of the examined population. This result considerably exceeded the expected malignant tumor detectability in the general population. Malignant tumors occurred more frequently in patients under 35 years compared to older persons. Also, cervical cancer as well as cancer of the urinary bladder, kidney and thyroid glands were diagnosed more frequently compared to the general population [13].

During the first decade of the $21^{\text {st }}$ century some epidemiologic data confirming previous findings were published in the world literature. In the study by Teschner et al., which was published in 2002 and included analysis of the medical records of 1727 hemodialyzed patients in Bavaria, malignant tumors were diagnosed in $7.2 \%$ of these patients. Similarly to previous studies, the diagnosis was made mainly within the first year of dialysis therapy and considerably less frequently in further years of renal replacement therapy.
According to this study, the greatest tumor incidence referred to patients aged 35-50 years. Most frequently, malignant tumor developed in kidneys, urinary bladder, prostatic gland, the liver, nasopharynx and lymphatic system. Compared to the general population, an increase in frequency was observed with respect to cancer of the mammary gland, stomach, colon, anus and bronchi. Since the number of patients with diagnosed malignant tumor in their material was very high, the authors suggested a necessity of running regular screening tests in hemodialyzed patients, especially in younger age groups, for the purpose of early diagnosis, particularly of cancer in the kidney, urinary bladder or the liver [14].

In the study by Lee et al. published in 2009 on 4562 patients dialyzed by hemodialysis or peritoneal dialysis in Korea and observed for 9 years, malignant tumors were observed in 106 patients, which amounted to $2.3 \%$ of the examined group. Most frequently, the sites of malignant tumors were as follows: digestive tract, urinary tract, lungs and thyroid gland. Mean time from dialysis therapy commencement to diagnosis of cancer was $75.2 \pm 63.9$ months. Mean time from cancer diagnosis to patient's death was two times shorter, approximately $36 \pm 30$ months. Similarly to other authors, Lee et al. recommended monitoring of cancer occurrence in dialyzed patients, especially with respect to digestive and respiratory tracts [15].

The only Polish study in this field was published by Antoni Sydor et al. in 2006 and involved a population of 5648 dialyzed patients including 5260 individuals receiving hemodialysis and 388 peritoneal dialysis. Malignant tumor was diagnosed in $9.5 \%$ of the patients in total. The most frequently diagnosed malignant tumors in women were mammary carcinoma and renal cell carcinoma (RCC), while in men they were renal cell carcinoma and lung cancer. Mean age of the examined group was 54 years, while the dialysis therapy period from cancer diagnosis was approximately 4 years [16].

Table 1 presents the most significant epidemiologic studies connected with occurrence of malignant tumors in the population of renal replacement therapy patients in the years 1975-2009.

The prevalence of RCC in patients with end-stage renal disease (ESRD) on dialysis is reported to be higher than in the general population, with a standardized incidence ratio (SIR) of 3.60 (3.45-3.76) [13]. The higher risk is probably attributed to the nature of the primary kidney disease, associated urological abnormalities or the development of renal acquired cystic kidney disease (ACKD) in dialyzed patients [17]. Within the first 3 years of dialysis therapy approximately $10-20 \%$ of patients develop ACKD, by 5 years $40-60 \%$ have ACKD and by ten years more than $90 \%$ exhibit ACKD [18]. Furthermore, ACKD is often associated with several pathological features, e.g. papillary tufts, cribriform lesions, atypical cysts and adenomas, which are morphologically and cytogenetically considered to be early neoplastic lesions [19].

The incidence of RCC in ACKD is reported to be three to six times higher than in the general population [20]. Historically, most tumors arising in the background of ACKD have been considered to be papillary RCC, accounting for $42-71 \%$ of cases [21, 22]. Contrary to this belief, Tickoo et al. have recently reported a wide spectrum of renal cell tumors aris- 
Table 1. The most significant epidemiologic studies connected with occurrence of malignant tumor in the population of renal replacement therapy patients in the years 1975-2009

\begin{tabular}{|c|c|c|c|c|}
\hline Authors & Work title & Population & $\begin{array}{c}\text { Neoplasm } \\
\text { detectability } \\
\text { in the examined } \\
\text { population }\end{array}$ & $\begin{array}{l}\text { The most common primary } \\
\text { site of malignant tumor }\end{array}$ \\
\hline $\begin{array}{l}\text { Matas et al. } \\
1975\end{array}$ & $\begin{array}{l}\text { Increased incidence of malignancy during chronic } \\
\text { renal failure }\end{array}$ & $\begin{array}{c}646 \\
H D, T N\end{array}$ & $1.6 \%$ & $\begin{array}{l}\text { respiratory system, } \\
\text { urinary system }\end{array}$ \\
\hline $\begin{array}{l}\text { Slifkin et al. } \\
1977\end{array}$ & Malignancy in end-stage renal disease & $\begin{array}{l}712 \\
H D\end{array}$ & $3.1 \%$ & $\begin{array}{l}\text { respiratory system, } \\
\text { prostate gland }\end{array}$ \\
\hline $\begin{array}{l}\text { Kinlen et al. } \\
1980\end{array}$ & Cancer in patients receiving dialysis & $\begin{array}{c}1651 \\
\mathrm{HD}, \mathrm{DO}, \mathrm{TN}\end{array}$ & $0.9 \%$ & lymphatic system \\
\hline $\begin{array}{l}\text { Bush et al. } \\
1984\end{array}$ & Cancer in uremic patients & $\begin{array}{c}834 \\
D\end{array}$ & $0.8 \%$ & non-specific \\
\hline $\begin{array}{l}\text { Port et al. } \\
1989\end{array}$ & $\begin{array}{l}\text { Neoplasms in dialysis patients: } \\
\text { a population-based study }\end{array}$ & $\begin{array}{c}4161 \\
D\end{array}$ & & $\begin{array}{l}\text { urinary system, uterine } \\
\text { body, prostate gland }\end{array}$ \\
\hline $\begin{array}{l}\text { Pecqueux et al. } \\
1990\end{array}$ & $\begin{array}{l}\text { Cancer incidence in patients on chronic dialysis } \\
\text { and in renal transplant recipients }\end{array}$ & $\begin{array}{c}317 \\
D\end{array}$ & $\begin{array}{c}0.4 \% \\
1\end{array}$ & urinary system \\
\hline $\begin{array}{l}\text { Inamoto et al. } \\
1991\end{array}$ & $\begin{array}{l}\text { Incidence and mortality pattern of malignancy and factors } \\
\text { affecting the risk of malignancy in dialysis patients }\end{array}$ & $\begin{array}{c}23209 \\
\text { D }\end{array}$ & $0.48 \%$ & $\begin{array}{l}\text { digestive system, } \\
\text { urinary system }\end{array}$ \\
\hline $\begin{array}{l}\text { Čučković et al. } \\
1996\end{array}$ & Malignant tumors in hemodialysis patients & $\begin{array}{l}923 \\
H D\end{array}$ & $4.9 \%$ & urinary system \\
\hline $\begin{array}{l}\text { Maisonneuve et al. } \\
1999\end{array}$ & $\begin{array}{l}\text { Cancer in patients on dialysis for end-stage renal disease: } \\
\text { an international collaborative study }\end{array}$ & $\begin{array}{l}831804 \\
H D, D O\end{array}$ & $3 \%$ & urinary system \\
\hline $\begin{array}{l}\text { Tischner et al. } \\
2002\end{array}$ & $\begin{array}{l}\text { Incidence and spectrum of malignant disease among } \\
\text { dialysis patients in North Bavaria }\end{array}$ & $\begin{array}{l}1727 \\
H D\end{array}$ & $7.2 \%$ & urinary system \\
\hline $\begin{array}{l}\text { Lee et al. } \\
2009\end{array}$ & Cancer in patients on chronic dialysis in Korea & $\begin{array}{c}4562 \\
3011 / 1551 \\
\text { HD, DO }\end{array}$ & $2.3 \%$ & $\begin{array}{l}\text { digestive system, urinary } \\
\text { system, respiratory } \\
\text { system, thyroid }\end{array}$ \\
\hline $\begin{array}{l}\text { Sydor et al. } \\
2006\end{array}$ & $\begin{array}{l}\text { Malignant tumors in chronic kidney } \\
\text { disease patients }\end{array}$ & $\begin{array}{c}5648 \\
5260 / 388 \\
H D, D O\end{array}$ & $9.5 \%$ & urinary tract, lung, breast \\
\hline
\end{tabular}

HD - hemodialysis; DO - peritoneal dialysis; TN - transplantation; D - dialyzed (with no method specified)

ing in ESRD, with a majority, particularly those arising in ACKD, showing morphologic features that are not seen in renal tumors in a sporadic setting [23]. The authors tentatively designate such tumors as ACKD-associated RCC. The reasons for their not considering ACKD-associated RCC as a papillary RCC are primarily based on the combination of morphologic features in these tumors, which include:

1) the unique cribriform architecture almost invariably present, either focally or diffusely (in $96 \%$ of tumors),

2) the consistent presence of eosinophilic cells in each tumor with grade 3 nuclei,

3) the frequent presence of intratumoral oxalate crystals. The biologic behavior of RCCS in ESRD is reported to be less aggressive than the RCCS in a sporadic or non-ESRD setting [17, 24-28]. However, rare cases have been reported to behave aggressively and metastasize. One of the possible reasons for this less aggressive behavior may be that these patients are usually under constant medical care, and radiologic evaluations may identify most tumors quite early [23].

Table 2 presents the clinicopathologic characteristics of renal cell carcinoma in patients with end-stage renal disease on dialysis.
To conclude, the described outcomes of epidemiologic studies indicate that routine screening tests for neoplastic disease are justified at least in particular groups of patients who receive renal replacement therapy, especially hemodialyzed individuals.

\section{Screening and diagnostic tests for malignant tumor in dialyzed patients: if and when?}

In 2008 Mandayam et al. suggested that regular screening tests be performed for neoplastic disease in the population of dialyzed patients. In the case of men the tests would refer to prostatic gland and kidney, in women to digestive tract and mammary glands [29]. Table 3 presents the usefulness of neoplastic markers used in patients on renal replacement therapy.

As the table suggests, very few markers have similar diagnostic value to the ones used for the general population. The other markers either have high false positive rates or should be interpreted very carefully.

Rao et al. recommend careful interpretation of neoplastic markers excreted by kidneys. The markers are proteins of a rel- 
Table 2. The clinicopathologic characteristics of renal cell carcinoma in patients with end-stage renal disease on dialysis

\begin{tabular}{|c|c|c|c|c|c|c|c|c|}
\hline Authors & Population & $\begin{array}{c}\text { Number } \\
\text { of patients } \\
\text { with RCC } \\
\text { (male : } \\
\text { female) }\end{array}$ & $\begin{array}{l}\text { Median } \\
\text { age } \\
\text { (range) }\end{array}$ & $\begin{array}{l}\text { Time on } \\
\text { dialysis } \\
\text { to diagnosis } \\
\text { of RCC mean } \\
\text { (range) }\end{array}$ & Treatment & Histology & $\begin{array}{l}\text { Follow-up } \\
2 \text { years } \\
\text { (survival) }\end{array}$ & Conclusion \\
\hline $\begin{array}{l}\text { Hora } \\
\text { et al. }\end{array}$ & NR & $13: 1$ & $53(41-78)$ & $\begin{array}{l}78 \text { mos. } \\
(0-154)\end{array}$ & $\begin{array}{l}13 \text { unilateral } \\
\text { nephrectomy, } \\
6 \text { bilateral } \\
\text { nephrectomy }\end{array}$ & $\begin{array}{l}\text { multifocal 68.4\% } \\
(13 / 19), \\
\text { solitary } 31.6 \%(6 / 19) \text {, } \\
\text { PRCC }-68.4 \%(13 / 19 \\
\text { CRCC }-47.4 \%(9 / 19) \\
\text { PR/CR }-21.0 \%(4 / 19)\end{array}$ & $\begin{array}{l}74 \% \\
\text { ), } \\
\text { (9), }\end{array}$ & $\begin{array}{l}\text { There is a high risk for bilateral RCC } \\
\text { Patients who undergo unilateral } \\
\text { nephrectomy must be regularly } \\
\text { followed and contralateral } \\
\text { nephrectomy carefully considered }\end{array}$ \\
\hline $\begin{array}{l}\text { Nouh } \\
\text { et al. }\end{array}$ & 1200 & $31: 3$ & $56(32-82)$ & $\begin{array}{l}116.5 \text { mos. } \\
(1-390)\end{array}$ & $\begin{array}{l}34 \text { nephre- } \\
\text { ctomy }\end{array}$ & $\begin{array}{l}\text { multifocal 27\% } \\
(9 / 34), \\
\text { CRCC - 37\% (10/27), } \\
\text { PRCC - } 7.4 \%(2 / 27), \\
\text { PR/CR - } 7.4 \%(2 / 27) \text {, } \\
\text { ACD - associated, } \\
\text { RCC - } 27 \%(8 / 27)\end{array}$ & $88.9 \%$ & $\begin{array}{l}\text { The spectrum of histological types } \\
\text { of RCCS arising in ESRD is distinct } \\
\text { from that of sporadic RCC ACKD } \\
\text { in patients with ESRD and on } \\
\text { dialysis is a potential risk factor } \\
\text { for the development of RCCS }\end{array}$ \\
\hline $\begin{array}{l}\text { Tickoo } \\
\text { et al. }\end{array}$ & NR & $34: 18$ & $56.5(30-78)$ & 8 yr (1-17) & $\begin{array}{l}37 \text { unilateral } \\
\text { nephrectomy, } \\
\text { bilateral } 15\end{array}$ & $\begin{array}{l}\text { multifocal } 54.5 \% \\
(36 / 66), \\
\text { PRCC }-18 \%(12 / 66) \text {, } \\
\text { ACD-RCC - 36\% } \\
(24 / 66) \\
\text { CRCC }(25 / 66)\end{array}$ & $\begin{array}{c}34 \\
\text { mos. } \\
\text { (range } \\
9-94 \\
\text { mos.) }\end{array}$ & $\begin{array}{l}\text { Acquired cystic disease-associated } \\
\text { RCC is the commonest tumor } \\
\text { subtype in ESRD }\end{array}$ \\
\hline $\begin{array}{l}\text { Hurst } \\
\text { et al. }\end{array}$ & 495.604 & $3875: 2257$ & NR & NR & NR & $\begin{array}{l}\text { ACD-RCC }-12.1 \% \\
(742 / 6132)\end{array}$ & $\begin{array}{l}\text { follow- } \\
\text {-up } 8 \text { yr }\end{array}$ & $\begin{array}{l}\text { Among long-term incident US } \\
\text { dialysis patients over an 8-year } \\
\text { period, most cases of RCC } \\
\text { diagnosed were not associated with } \\
\text { documented acquired renal cystic } \\
\text { disease }\end{array}$ \\
\hline $\begin{array}{l}\text { Kojima } \\
\text { et al. }\end{array}$ & 2624 & $31: 13$ & $55.5 \pm 11.1$ & $\begin{array}{l}11.2 \mathrm{yr} \pm \\
7.2 \mathrm{yr}\end{array}$ & $\begin{array}{l}44 \text { unilateral } \\
\text { nephrectomy, } \\
5 \text { bilateral }\end{array}$ & $\begin{array}{l}\text { CRCC }-47 \% \\
(23 / 49), \\
\text { PRCC }-8.2 \%(4 / 49), \\
\text { ChCC }-8.2 \%(4 / 49), \\
\text { ACD-RCC }-36.7 \% \\
(18 / 49)\end{array}$ & $\begin{array}{l}\text { follow- } \\
\text { up } 36 \\
\text { mos. } \\
\text { range, } \\
6-121\end{array}$ & $\begin{array}{l}\text { Dialysis in patients showed a higher } \\
\text { incidence of RCC than the general } \\
\text { population }\end{array}$ \\
\hline $\begin{array}{l}\text { Satoh } \\
\text { et al. }\end{array}$ & 6201 & $30: 8$ & 56.5 & $\begin{array}{l}143.2 \\
\text { mos. }\end{array}$ & $\begin{array}{l}33 \\
\text { nephrectomy }\end{array}$ & NR & $\begin{array}{l}88.9 \% \\
(5 \mathrm{yr} \\
\text { survival) }\end{array}$ & $\begin{array}{l}\text { Long-term dialysis is a risk factor for } \\
\text { RCC }\end{array}$ \\
\hline
\end{tabular}

$R C C$ - renal cell carcinoma; $P R C C$ - papillary renal cell carcinoma; CRCC - clear cell renal cell carcinoma; $P R / C C$ - clear cell/papillary renal cell carcinoma; $A C D-R C C$ - renal cell carcinoma associated with acquired cystic kidney disease; NR - not reported; yr -year; mos. - months

atively high molecular weight and are not necessarily removed by dialysis, leading to false test results. These observations referred to Ca 125 neoplastic antigen, carcinoembryonic antigen (CEA), squamous cell carcinoma antigen (SCC) and neuron-specific enolase (NSE) [30].

The following problem has been discussed in recent years: should dialyzed patients undergo screening diagnostics similar to the general population or should these tests be limited to the groups with particular risk of developing neoplastic diseases. Such groups would include:

- hemodialyzed patients, especially in the $3^{\text {rd }}-4^{\text {th }}$ decade of life;

- individuals with genetic predisposition for developing neoplastic disease;

- individuals on hemodialysis, peritoneal dialysis and patients prepared for kidney transplantation;

- individuals with longer life expectancy.
Table 3. Specificity and sensitivity of particular markers of neoplastic diseases in dialyzed patients

\begin{tabular}{ll} 
Usefulness & Marker \\
$\begin{array}{l}\text { Infallible in } \\
\text { dialyzed patients }\end{array}$ & $\begin{array}{l}\alpha \text {-fetoprotein } \\
\beta \text {-chorionic gonadotropin } \\
\text { PSA }\end{array}$ \\
\hline Interpret carefully & Ca 125 \\
& CA 50 \\
CA 19.9
\end{tabular}

Table 4 presents our modification of suggested screening tests for neoplastic disease in dialyzed patients [31]. 
Table 4. Suggestions of screening test in dialyzed patients with consideration of carcinogenesis risk factors, life expectancy and transplant status ( ${ }^{*}$ own modification)

\begin{tabular}{|c|c|}
\hline Malignant tumor & Suggested procedure \\
\hline Breast cancer & $\begin{array}{l}\text { Annual mammogram in women over } 40 \text { years of age } \\
\text { Annual clinical breast test at the age of } 40 \text { and more; every } 3 \text { years self check for women aged } 20-39 \text { years } \\
\text { In women from families with high risk of hereditary breast cancer consider intensification of screening tests }\end{array}$ \\
\hline Colorectal cancer & $\begin{array}{l}\text { Screening tests in patients over } 50 \text { years of age based on annual fecal occult blood test or immunochemical } \\
\text { fecal test for patients waiting for kidney transplant } \\
\text { Sigmoidoscopy, colonoscopy or double contrast barium enema is needed } \\
\text { Consider intensification of screening test in patients with family-related higher risk of hereditary colorectal } \\
\text { cancer and at the same time long life expectancy }\end{array}$ \\
\hline Cervical cancer & $\begin{array}{l}\text { Papanicolaou test once a year; the first no later than at the age of } 21 \text { years } \\
\text { For consideration: vaccination against HPV, especially in women waiting for transplant; annual Papanicolaou } \\
\text { test in women waiting for transplant and with risk factors and at the same time long life expectancy }\end{array}$ \\
\hline Prostatic cancer & $\begin{array}{l}\text { PSA and rectal exam once a year starting from the age of } 50 \text { years in men waiting for transplant } \\
\text { Consider screening tests in men with high risk of developing disease and at the same time long life expectancy }\end{array}$ \\
\hline Kidney cancer & $\begin{array}{l}\text { Once a year computed tomography ( }{ }^{*} \text { carefully in the case of contrast tests due to negative impact on residual } \\
\text { diuresis) or MRI (*risk of nephrogenic systemic fibrosis after gadolinium or Magnevist) in patients dialyzed } \\
\text { for over } 3 \text { years or waiting for transplant }\end{array}$ \\
\hline
\end{tabular}

When deciding on indications for various diagnostic tests, their limitations should be taken into consideration. Detection of calcification in chest vessels in women with chronic mineral kidney disease (CMKD) might give false mammography results. Suspected digestive tract neoplasm based on presence of fecal occult blood might be false positive due to frequent occurrence of digestive tract mucosa inflammation or vascular malformation that promotes bleeding in this group of patients. Computed tomography with contrast medium, especially in dehydrated patients, might cause a decline in kidney function in pre-dialysis patients (eGFR > $15 \mathrm{ml} / \mathrm{min} / 1.73 \mathrm{~m}^{2}$ ) or a decrease in residual diuresis in dialyzed patients. Magnetic resonance with the use of paramagnetic agents listed in Table 3 is related to the risk of nephrogenic systemic fibrosis [30].

Considering the indisputable fact that malignant tumors occur frequently in renal replacement therapy patients, especially hemodialyzed individuals, particular groups of patients should undergo regular screening tests, especially for the most common neoplasms such as renal or urinary bladder cancer. When deciding whether to run the tests, the patient's life expectancy should also be taken into consideration.

The authors declare no conflict of interest.

\section{References}

1. Rutkowski B, Lichodziejewska-Niemierko M, Grenda R, Czekalski S, Durlik M, Bautembach S. Raport o stanie leczenia nerkozastępczego w Polsce 2008. Drukonsul, Gdańsk 2010.

2. Matas AJ, Simmons RL, Kjellstrand CM, Buselmeier TJ, Najarian JS. Increased incidence of malignancy during chronic renal failure. Lancet 1975; 1: 883-6.

3. Kjellstrand CM. Are malignancies increased in uremia? Nephron 1979; 23: 159-61.

4. Kinlen LJ, Eastwood JB, Kerr DN, Moorhead JF, Oliver DO, Robinson BH, de Wardener HE, Wing AJ. Cancer in patients receiving dialysis. $\mathrm{Br}$ Med I 1980; 280: 1401-3.
5. Slifkin RF, Goldberg J, Neff MS, Baez A, Mattoo N, Gupta S. Malignancy in end-stage renal disease. Trans Am Soc Artif Intern Organs 1977; 23: 34-40.

6. Jacobs C, Brunner FP, Brynger $\mathrm{H}$, et al. Malignant diseases in patients treated by dialysis and transplantation in Europe. Transplant Proc 1981; 13: 729-32.

7. Lindner A, Farewell VT, Sherrard DJ. High incidence of neoplasia in uremic patients receiving long-term dialysis. Cancer and long-term dialysis. Nephron 1981; 27: 292-6.

8. Bush A, Gabriel R. Cancer in uremic patients. Clin Nephrol 1984; 22: 77-81.

9. Port FK, Ragheb NE, Schwartz AG, Hawthorne VM. Neoplasms in dialysis patients: a population-based study. Am J Kidney Dis 1989; 14 119-23.

10. Pecqueux JC, Schwarz A, Dieckmann KP, Offermann G. Cancer incidence in patients on chronic dialysis and in renal transplant recipients. Urol Int 1990; 45: 290-2.

11. Inamoto H, Ozaki R, Matsuzaki T, Wakui M, Saruta T, Osawa A. Incidence and mortality pattern of malignancy and factors affecting the risk of malignancy in dialysis patients. Nephron 1991; 59: 611-7.

12. Cucković C, Djukanović L, Janković S, et al. Malignant tumors in hemodialysis patients. Nephron 1996; 73: 710-2.

13. Maisonneuve P, Agodoa L, Gellert R, et al. Cancer in patient on dialysis for end-stage renal disease: an international collaborative study. Lancet 1999; 354: 93-9.

14. Teschner M, Garte C, Rückle-Lanz H, Mäder U, Stopper H, Klassen A, Heidland $A$. Incidence and spectrum of malignant disease among dialysis patients in North Bavaria. Dtsch Med Wochenschr 2002; 127: 2497-502.

15. Lee JE, Han SH, Cho BC, et al. Cancer in patient on chronic dialysis in Korea. J Korean Med Sci 2009; 24 Suppl: S95-S101.

16. Sydor A, Czapkowicz-Gryszkiewicz L, Didkowska J, Sułowicz W, Gel ert R. Nefroonkologia. Problemy Lekarskie 2006; 45: 159-60.

17. Satoh S, Tsuchiya N, Habuchi T, Ishiyama T, Seimo K, Kato T. Renal cell and transitional cell carcinoma in a Japanese population undergoing maintenance dialysis. J Urol 2005; 174: 1749-53.

18. Choyke PL. Acquired cystic kidney disease. Eur Radiol 2000; 10: 1716-21.

19. Truong LD, Choi YJ, Shen SS, Ayala G, Amato R, Krishnan B. Renal cystic neoplasms and renal neoplasms associated with cystic renal diseases: pathogenetic and molecular links. Adv Anat Pathol 2003; 10: 135-59.

20. Ljungberg B, Campbell SC, Choi HY, Jacqmin D, Lee JE, Weikert S, Kiemeney LA. The epidemiology of renal cell carcinoma. Eur Urol 2011; 60: 615-21. 
21. Dhillon J, Amin MB, Selbs E, Turi GK, Paner GP, Reuter VE. Mucinous tubular and spindle cell carcinoma of the kidney with sarcomatoid change. Am J Surg Pathol 2009; 33: 44-9.

22. Sule N, Yakupoglu U, Shen SS, Krishnan B, Yang G, Lerner S, SheikhHamad D, Truong LD. Calcium oxalate deposition in renal cell carcinoma associated with acquired cystic kidney disease: a comprehensive study. Am J Surg Pathol 2005; 29: 443-51.

23. Denton MD, Magee CC, Ovuworie C, Mauiyyedi S, Pascual M, Colvin RB, Cosimi AB, Tolkoff-Rubin N. Prevalence of renal cell carcinoma in patients with ESRD pre-transplantation: a pathologic analysis. Kidney Int 2002; 61: 2201-9.

24. Hora M, Hes O, Reischig T, Urge T, Klecka J, Ferda J, Michal M, Eret V. Tumours in end-stage kidney. Transplant Proc 2008; 40: 3354-8.

25. Nouh MA, Kuroda N, Yamashita M, et al. Renal cell carcinoma in patients with end-stage renal disease: relationship between histological type and duration of dialysis. BJU Int 2010; 105: 620-7.

26. Tickoo SK, dePeralta-Venturina MN, Harik LR, Worcester HD, Salama ME, Young AN, Moch H, Amin MB. Spectrum of epithelial neoplasms in end-stage renal disease: an experience from 66 tumorbearing kidneys with emphasis on histologic patterns distinct from those in sporadic adult renal neoplasia. Am J Surg Pathol 2006; 30: 141-53.

27. Hurst FP, Jindal RM, Fletcher JJ, et al. Incidence, predictors and associated outcomes of renal cell carcinoma in long-term dialysis patients. Urology 2011; 77: 1271-6.

28. Kojima Y, Takahara S, Miyake O, Nonomura N, Morimoto A, Mori H. Renal cell carcinoma in dialysis patients: a single center experience. Int J Urol 2006; 13: 1045-8.

29. Mandayam S, Shahinian VB. Are chronic dialysis patients at increased risk for cancer. J Nephrol 2008; 21: 166-74.

30. Rao SN. Cancer screening in end-stage renal disease. Saudi J Kidney Dis Transpl 2009; 20: 737-40.

31. Holley JL Screening, diagnosis, and treatment of cancer in long-term dialysis patients. Clin J Am Soc Nephrol 2007; 2: 604-10.

\section{Address for correspondence}

\section{Grzegorz Kade}

Klinika Chorób Wewnętrznych, Nefrologii i Dializoterapii

Wojskowy Instytut Medyczny, CSK MON

Szaserów 128

00-909 Warszawa

tel./fax +48226816811

e-mail: gkade@wim.mil.pl

Submitted: 27.10.2011

Accepted: 15.02 .2012 